\title{
PERSONNEL SELECTION USING FUZZY AXIOMATIC DESIGN PRINCIPLES
}

\author{
Anant V. KHANDEKAR ${ }^{1}$, Shankar CHAKRABORTY ${ }^{2}$ \\ ${ }^{1}$ Department of Mechanical Engineering, Government Polytechnic, Bandra (East), \\ Mumbai - 400051, Maharashtra, India \\ ${ }^{2}$ Department of Production Engineering, Jadavpur University, Kolkata - 700 032, West Bengal, India \\ E-mails: ${ }^{1}$ anantkhandekar2709@gmail.com; ${ }^{2}$ __chakraborty00@yahoo.co.in (corresponding author)
}

Received 24 June 2015; accepted 14 January 2016

\begin{abstract}
Overall competency of the working personnel is often observed to ultimately affect the productivity of an organization. The globalised competitive atmosphere coupled with technological improvements demands for efficient and specialized manpower for the industrial operations. A set of typical technological skills and attitudes is thus demanded for every job profile. Most often, these skills and attitudes are expressed imprecisely and hence, necessitating the support of fuzzy sets for their effective understanding and further processing. In this paper, a method based on fuzzy axiomatic design principles is applied for solving the personnel selection problems. Selecting a middle management staff of a service department for a large scale organization is demonstrated here as a real life example. Five shortlisted candidates are assessed with respect to a set of 18 evaluation criteria, and the selection committee with experts from the related fields also realizes the outcome of the adopted approach to be quite appropriate, befitting and in agreement with their expectations.
\end{abstract}

Keywords: axiomatic design principles, fuzzy set theory, information content, personnel selection, manufacturing organization, rank.

JEL Classification: C80, D78, J23, M12, M51.

\section{Introduction}

Personnel selection for the present day manufacturing organizations is the specialized activity of appointing an employee with right set of skills and attitude according to the job's requirements. In other words, it is the recruitment activity aimed at singling out applicants with the required qualifications and keeping them interested with the organization so that they will accept a job offer when it is extended to them. Substantial research has been conducted on recruitment policy adaptation due to its critical role in bringing human capital into organizations (Safari et al. 2014). With the rapid industrialization since the last few decades, there has been a diversified spectrum of products manufactured and services offered. As a result of this, the job market has also naturally broadened multi-fold with the demand for working personnel with the required set of skills and performance. Hence, the task of recruiting the right type of personnel for the required job position has become very arduous, critical, and recently it has been emerged out to be an area of unparallel importance.

Different techniques, such as direct interviews, work sample tests, scrutiny of resumes, job knowledge tests and personality tests are generally employed for assessing the suitability of the candidates for a specific job position (Dodangeh et al. 2014). Also as against the traditional methods, a number of experts are generally involved in the selection committee to assess the suitability of candidates' technical knowledge, physical fitness, mental and psychological status, motor skills, social and environmental awareness and so forth. Therefore, multi-criteria decisionmaking (MCDM) techniques have been normally adopted for dealing with the personnel selection problems (Dursun, Karsak 2010).

Copyright $\odot 2016$ The Authors. Published by VGTU Press.

This is an open-access article distributed under the terms of the Creative Commons Attribution-NonCommercial 4.0 (CC BY-NC 4.0) license, which permits unrestricted use, distribution, and reproduction in any medium, provided the original author and source are credited. The material cannot be used for commercial purposes.

To link to this article: http://dx.doi.org/10.3846/btp.2016.660 
The activity of purchasing raw materials, semi-finished goods, sub-assemblies along with services for a large scale organization is a very critical issue as it accounts for approximately $60 \%$ of the organization's cost along with the realization that only 2 to $4 \%$ of the organization's personnel work is associated with this (Monczka et al.2009). Nowadays, the purchasing function is also called as "procurement", "sourcing" or "supply chain management". The responsibilities for purchasing are not limited just on placing a purchase order with the supplier and receiving the materials, but they extend far beyond these routine activities in today's purchasing context. It requires a sound knowledge and expertise in the fields of finance, engineering, quality and marketing management. The managerial level personnel executing the responsibilities of the said post should have a multi-faceted figure as he/she has to co-ordinate the activities with other departments, like design engineering for new product development/intermittent modifications, manufacturing/ operations, finance, distribution and customer service. The purchasing personnel should add value to the organization while carrying out various functions as leveraging purchases at lower price, managing the total cost of supply chain, reduce the administrative costs and cycle time, selecting the best suppliers and certifying them, and taking necessary corrective actions based on the pertinent feedbacks. So considering the strategic importance of purchasing function in a manufacturing organization, it is decided to select a Deputy Manager of purchase department for a large scale organization while exploring the potentiality of fuzzy axiomatic design (FAD) principles. For this purpose, a total of 18 relevant evaluation criteria under seven sub-groups, are identified for assessing the suitability of five alternative candidates. All the criteria are expressed in linguistic terms and the adopted methodology is found to be quite capable of processing these imprecise data.

As the contemporary jobs demand for specialized human resource skills, it has become mandatory for the organizational management to scrupulously assess the potential candidates with respect to various required skills and attitudes. So, as against the traditional approach of assessing the potential candidates using manual methods, it has been found to be more beneficial to have some analytical selection model/method for this purpose. Until now, several MCDM methods have been successfully applied for solving the personnel selection problems with heterogeneous set of criteria. Considerable research has been carried out in this field in the recent past and is reviewed as follows in Table 1.

From this review of the past literature, it is evident that the topic of personnel selection has been well researched for recruiting the employees at all hierarchical levels in almost all types of organizations. Various basic MCDM methods, like VIKOR, AHP, TOPSIS, GRA, ANP, DEA, ELECTRE, ARAS, SWARA, MULTIMOORA, PROMETHEE etc. have been employed along with fuzzy set theory for this purpose. The application area of axiomatic design (AD) principles for personnel selection seems to remain unexplored and hence, it is decided to validate its potentiality for selection of a critical post of Deputy Manager of a purchase department of an organization.

In the latter part of this paper, FAD methodology is described in Section 1. The proposed approach based on FAD methodology is presented in Section 2. A representative problem of personnel selection is solved in Section 3, followed by the concluding remarks in the last section.

\section{FAD methodology}

The principles of fuzzy set theory are more suitably utilized to handle the imprecise and ambiguous type of information involved in dealing with the personnel selection problems. Therefore, these principles along with $\mathrm{AD}$ theory basics are summarized as below.

\subsection{Fuzzy set theory}

Fuzzy logic (Zadeh 1996) is a branch of soft computing techniques and is capable of computing with words. When dealing with uncertainty, it becomes necessary for the DMs to evaluate alternatives or criteria in terms of linguistic variables, such as very low, low, medium, high and very high. This approach uses the form of interval analysis to handle inaccurate information and provides rational solutions for complex problems. A fuzzy number belongs to the closed interval 0 and 1 , where 1 addresses full membership and 0 expresses non-membership. Fuzzy numbers can be of almost any shape, but frequently, they are triangular, pi-shaped and trapezoidal. In this paper, triangular fuzzy numbers (TFNs) are used due to their computational simplicity.

Table 1. Review of the past literature

\begin{tabular}{|c|l|l|l|}
\hline Sl. No. & \multicolumn{1}{|c|}{ Researcher and year } & \multicolumn{1}{|c|}{ Type of personnel selected } & \multicolumn{1}{c|}{ Methodology applied } \\
\hline 1. & Straub and Mossel (2007) & Maintenance contractor & Performance-based maintenance partnerships \\
\hline 2. & Güngör et al. (2009) & Not specific & $\begin{array}{l}\text { Fuzzy analytic hierarchy process (AHP) and computer-based } \\
\text { decision support system }\end{array}$ \\
\hline 3. & Celik et al. (2009) & $\begin{array}{l}\text { Academic personnel in Maritime } \\
\text { Education and Training } \\
\text { institutions }\end{array}$ & $\begin{array}{l}\text { Fuzzy AHP based on Buckley's algorithm and fuzzy technique for } \\
\text { order preference by similarity to ideal solution (TOPSIS) }\end{array}$ \\
\hline
\end{tabular}


End of Table 1

\begin{tabular}{|c|c|c|c|}
\hline 4. & $\begin{array}{l}\text { Dursun and Karsak } \\
(2010)\end{array}$ & Industrial engineer & $\begin{array}{l}\text { A fuzzy MCDM model with 2-tuple linguistic representation, } \\
\text { TOPSIS and ordered weighted averaging operator }\end{array}$ \\
\hline 5. & $\begin{array}{l}\text { Kelemenis and Askounis } \\
(2010)\end{array}$ & Top official of an IT company & Fuzzy TOPSIS method with veto threshold \\
\hline 6. & $\operatorname{Lin}(2010)$ & Electrical engineer & $\begin{array}{l}\text { Integrated analytic network process (ANP) and fuzzy data } \\
\text { envelopment analysis (DEA) }\end{array}$ \\
\hline 7. & Afshari et al. (2010) & $\begin{array}{l}\text { Telecommunication company } \\
\text { personnel }\end{array}$ & Simple additive weighting \\
\hline 8. & Dağdeviren (2010) & $\begin{array}{l}\text { Personnel for a manufacturing } \\
\text { company }\end{array}$ & ANP and TOPSIS \\
\hline 9. & Dereli et al. (2010) & $\begin{array}{l}\text { Industrial engineer for a } \\
\text { packaging company }\end{array}$ & $\begin{array}{l}\text { Preference ranking organization method for enrichment evaluation } \\
\text { (PROMETHEE) with fuzzy interface }\end{array}$ \\
\hline 10. & $\begin{array}{l}\text { Shahhosseini and Sebt } \\
\text { (2011) }\end{array}$ & $\begin{array}{l}\text { Human resources to } \\
\text { construction projects }\end{array}$ & AHP and an adaptive neuro-fuzzy inference system \\
\hline 11. & Zhang and Liu (2011) & $\begin{array}{l}\text { System analysis engineer for } \\
\text { software company }\end{array}$ & $\begin{array}{l}\text { An intuitionistic fuzzy MCDM method with grey relational analysis } \\
\text { (GRA) }\end{array}$ \\
\hline 12. & Rashidi et al. (2011) & Construction project manager & Fuzzy system based on IF-THEN rules with genetic algorithm \\
\hline 13. & Boran et al. (2011) & $\begin{array}{l}\text { Sales manager in a } \\
\text { manufacturing company }\end{array}$ & Intuitionistic fuzzy TOPSIS method \\
\hline 14. & $\begin{array}{l}\text { Keršulienè and Turskis } \\
(2011)\end{array}$ & Architect & $\begin{array}{l}\text { Additive ratio assessment method with fuzzy numbers (ARAS-F) } \\
\text { and step-wise weight assessment ratio analysis (SWARA) technique }\end{array}$ \\
\hline 15. & Matin et al. (2011) & Not specific & Fuzzy TOPSIS \\
\hline 16. & Akhlaghi (2011) & $\begin{array}{l}\text { IT professionals for an } \\
\text { engineering company }\end{array}$ & Rough set exploration system \\
\hline 17. & Chen et al. (2011) & $\begin{array}{l}\text { An engineer for a semi- } \\
\text { conductor industry }\end{array}$ & $\begin{array}{l}\text { Fuzzy Vlsekriterijumska Optimizacija I Kompromisno Resenje } \\
\text { (VIKOR) method }\end{array}$ \\
\hline 18. & Kelemenis et al. (2011) & Manager & $\begin{array}{l}\text { TOPSIS with new concepts like relative importance of the decision } \\
\text { makers (DMs) per criterion, similarity-proximity degree among the } \\
\text { DMs and veto thresholds }\end{array}$ \\
\hline 19. & Gilan et al. (2012) & $\begin{array}{l}\text { Project manager and engineer } \\
\text { for a construction industry }\end{array}$ & $\begin{array}{l}\text { Computing with words based on linguistic weighted average using } \\
\text { interval type- } 2 \text { fuzzy sets }\end{array}$ \\
\hline 20. & Baležentis et al. (2012) & Not specific & $\begin{array}{l}\text { Fuzzy multiplicative form of multi-objective optimization by ratio } \\
\text { analysis for group decision making (MULTIMOORA-FG) with } \\
\text { aggregation of subjective assessments }\end{array}$ \\
\hline 21. & $\begin{array}{l}\text { Wan et al. } \\
(2013)\end{array}$ & $\begin{array}{l}\text { Manager of an investment } \\
\text { company }\end{array}$ & VIKOR method with triangular intuitionistic fuzzy numbers \\
\hline 22. & $\begin{array}{l}\text { Rouyendegh and Erkan } \\
(2013)\end{array}$ & Academic staff of a university & $\begin{array}{l}\text { Fuzzy Elimination Et Choix Traduisant la REaite (ELECTRE) } \\
\text { method }\end{array}$ \\
\hline 23. & $\begin{array}{l}\text { Baležentis and Zeng } \\
(2013)\end{array}$ & $\begin{array}{l}\text { Manager ( } \mathrm{R} \& \mathrm{D}) \text { of a } \\
\text { telecommunication company }\end{array}$ & MULTIMOORA with generalized interval-valued fuzzy numbers \\
\hline 24. & Bali et al. (2013) & $\begin{array}{l}\text { Director (system analysis and } \\
\text { design) }\end{array}$ & Delphi technique based on intuitionistic fuzzy sets \\
\hline 25. & Javadein et al. (2013) & Human resource manager & Logarithmic fuzzy preference programming and TOPSIS \\
\hline 26. & Nobari and Zadeh (2013) & Not specific & Fuzzy TOPSIS \\
\hline 27. & Aggarwal (2013) & IT professionals & AHP with weighted fuzzy linear programming model \\
\hline 28. & $\begin{array}{l}\text { Kumaran and Sankar } \\
(2013)\end{array}$ & Not specific & Ontology mapping as e-recruitment method \\
\hline 29. & Özdemir (2013) & $\begin{array}{l}\text { Personnel for a textile } \\
\text { manufacturer }\end{array}$ & AHP with stochastic dynamic programming \\
\hline 30. & Sîrb and Dragolea (2013) & Not specific & Fuzzy software tool developed in Java programming language \\
\hline 31. & Saad et al. (2014) & $\begin{array}{l}\text { Personnel in an academic } \\
\text { institution }\end{array}$ & $\begin{array}{l}\text { Hamming distance method with subjective and objective weights } \\
\text { along with fuzzy set theory }\end{array}$ \\
\hline 32. & Chaghooshi et al. (2014) & Not specific & AHP with similarity-based method \\
\hline 33. & Afshari et al. (2013) & Project manager & Fuzzy integral method \\
\hline 34. & Safari et al. (2014) & Not specific & Combined TOPSIS and Hungary assignment approach \\
\hline
\end{tabular}




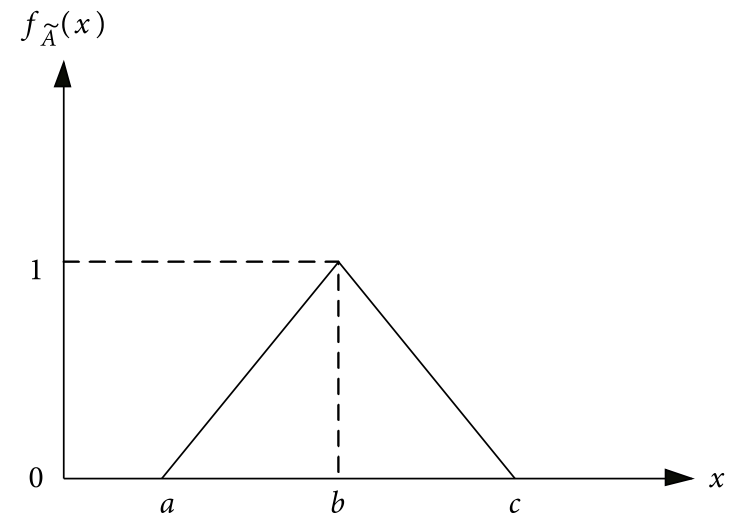

Fig. 1. Membership function for a TFN

Figure 1 depicts the membership function of a TFN denoted by $(a, b, c)$. This TFN starts rising from 0 at $x=a$, reaches a maximum of 1 at $x=b$, and declines to 0 at $x=c$. Let it be represented as $\tilde{A}$. Then, the membership function $f_{\tilde{A}}(x)$ of a TFN $\tilde{A}$ is given as follows:

$$
\begin{aligned}
f_{\tilde{A}}(x) & =(x-a) /(b-a), \quad a \leq x \leq b \\
& =(x-c) /(b-c), \quad b \leq x \leq c
\end{aligned} .
$$

This TFN is a function whose domain is a set of non-negative real numbers between $a$ and $c$. Each real number in this domain has a certain value of grade of membership. The smallest and the largest grade of membership are 0 and 1 respectively. So as evident from Figure 1, out of the three elements $a, b, c$ of $\tilde{A}$, membership grade of $a$ and $c$ is 0 and that of $b$ is 1. For any real number $x$ between $a$ and $c$, the value of membership grade can be calculated using Eq. 1 . So by assigning a TFN to denote any uncertain data value, an effort is made to quantify it by certain value of membership grade.

The basic algebraic operations of addition, subtraction, multiplication and division on two TFNs represented as $\tilde{A}_{1}=\left(a_{1}, b_{1}, c_{1}\right)$ and $\tilde{A}_{2}=\left(a_{2}, b_{2}, c_{2}\right)$ can be expressed as follows:

Addition and subtraction:

$$
\tilde{A}_{1} \pm \tilde{A}_{2}=\left(a_{1} \pm a_{2}, b_{1} \pm b_{2}, c_{1} \pm c_{2}\right) .
$$

Multiplication: $\tilde{A}_{1} \times \tilde{A}_{2} \cong\left(a_{1} a_{2}, b_{1} b_{2}, c_{1} c_{2}\right)$;

$$
k \times \tilde{A}_{2}=\left(k a_{2}, k b_{2}, k c_{2}\right),
$$

where $\mathrm{k}$ is a non-zero constant.

$$
\text { Division: } \frac{\tilde{A}_{1}}{\tilde{A}_{2}} \cong\left(\frac{a_{1}}{a_{2}}, \frac{b_{1}}{b_{2}}, \frac{c_{1}}{c_{2}}\right) \text {. }
$$

\subsection{FAD principles}

The concept of AD was proposed by Suh (1990) as a scientific and engineering approach for the design of products. As a result, the design process became more systematic by providing the designer with a theoretical foundation based on logical and rational thought process and tools (Suh 2001). The AD principles allow for the selection of not only the best alternative within a set of criteria, but also the most appropriate alternative. It is the main difference between the classical MCDM methods and AD principles (Kannan et al. 2015). Some recent applications of FAD principles in the field of decision-making can be summarized as follows. Cicek and Celik (2010) solved material selection problems using a modified FAD model. Boran et al. (2012) evaluated various energy policies for Turkey using FAD principles. Büyüközkan (2012) applied FAD principles for green supplier evaluation as a part of purchasing function of the organizations. $\mathrm{Li}$ (2013) extended $\mathrm{AD}$ principles in intuitionistic fuzzy environment for selection of the best knowledge map designs. Beng and Omar (2014) showed that FAD approach could be effective while dealing with problems concerning green supplier selection and optimization of manufacturing solution.

This method takes into consideration the customer needs related to a product to be incorporated in terms of functional requirements (FRs) and establishes the relation with the final design parameters (DPs) of the product. In the present context of decision-making, FRs represent various criteria with respect to which suitability of an alternative is to be judged for its intended function.

In $\mathrm{AD}$ theory, the DPs are expressed in terms of range of values. Usually, this range is fixed by the designer or DM and is known as design range (DR). The values of FRs corresponding to various alternatives expressed by means of linguistic terms or numerical ranges or numerical approximations are known as system range (SR) values of the alternatives. In the case of design of products, the designer has to choose the optimal solution from different feasible design solutions by the application of $\mathrm{AD}$ principles. This capability of $\mathrm{AD}$ theory of selecting the most optimal design solution also comes as a handy tool for decision-making. This task of decision-making is assisted by the two underlying axioms of $\mathrm{AD}$ theory.

\subsubsection{Independence axiom}

Independence axiom states that a particular FR should be fulfilled independently by a certain DP without affecting the other FRs. In real time situations also, a given complex design or a decision task is decomposed into smaller components and the independent solution for each of them is sought so as to simplify the main task. So, the independence axiom is based on this analogy. In the context of decision-making, shortlisting of different feasible alternatives for carrying out a designated task is the outcome of the application of independence axiom.

\subsubsection{Information axiom}

Under the preview of this axiom, information content (IC) is calculated for all the design solutions satisfying the first 
axiom, i.e. the independence axiom. Information axiom states that the alternative with the minimum $I C$ value is the optimal choice (Suh 2001). The IC is related in its simplest form to the probability of satisfying a given FR. It determines that the design with the highest probability of success is the best design. The $I C_{i}$ value for a given $F R_{i}$ is defined using the following equation:

$$
\mathrm{IC}_{i}=\log _{2}\left(\frac{1}{p_{i}}\right)=-\log _{2}\left(p_{i}\right)
$$

where $p_{i}$ is the probability of satisfying $F R_{i}^{\prime}$. The information is expressed in units of bits. The logarithmic function is chosen so that the $I C$ values will be additive when there are many FRs that must be satisfied simultaneously and the logarithm is based on 2 which is the unit of bits of information. For the value of $p_{i}$ equal to zero, the $I C$ value becomes infinite and the corresponding alternative thus gets rejected. Conversely, for the value of $p_{i}$ equal to one, the $I C$ value is zero and it is the ideal case of the selected alternative solution. The DR is decided by the designer or $\mathrm{DM}$ and it is the ideal range of values to be tried to achieve in the design process. The capability of each alternative to satisfy the desired FRs is expressed in terms of SR values.

As shown in Figure 2, the overlap between the designer-specified DR and the SR is known as "common range" (CR), where the acceptable solutions exist. In this case, SR and DR values are expressed in terms of range of crisp values. It is a representation of the application of AD methodology in its crisp form. So, there is definite knowledge about performance capability of the concerned alternative in accomplishing a given task. Therefore, this is the case of uniform probability distribution function wherein the range values of $S R$ and $C R$ are obtained as the numerical gap between two end values of a range. The value of $p_{i}$ is thus given as follows:

$$
p_{i}=\left(\frac{\mathrm{CR}}{\mathrm{SR}}\right) \text {. }
$$

So, the value of $I C$ can now be expressed as below:

$$
\mathrm{IC}_{i}=\log _{2}\left(\frac{\mathrm{SR}}{\mathrm{CR}}\right) \text {. }
$$

Figure 3 represents the case of application of $\mathrm{AD}$ in fuzzy environment. Here, the capability of satisfying a certain task, i.e. $F R_{i}$ value is not given in terms of a discreet range of numerical values, but it is expressed by a fuzzy membership function. In other words, it can be said that the system range capability of an alternative represented by a fuzzy number takes the shape of a curve denoted as System $p d f$ within the limits of SR, as shown in Figure 3. So as against the previous case of uniform probability distribution function, it is the case of variable probability density function (pdf). $F R_{i}$ is a continuously varying random variable. In general, the area bounded by the curve of system pdf and $\mathrm{x}$-axis is equal to 1 when computed over

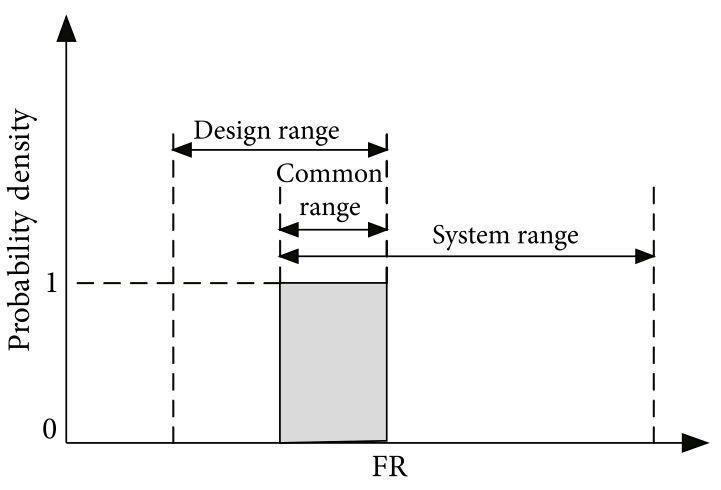

Fig. 2. Design range, system range and common range for FR

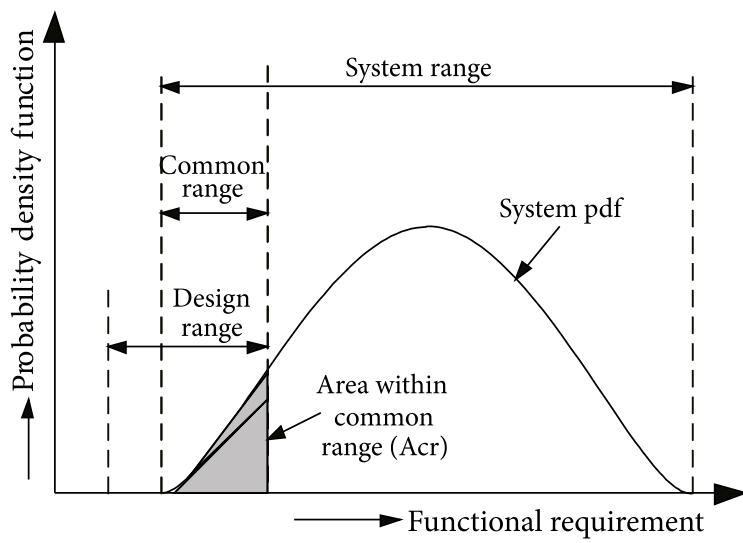

Fig. 3. Design range, system range, common range and system pdf for a FR

the entire domain of SR and represents the probability of achieving $F R_{i}$. On the other hand, the probability of achieving $F R_{i}$ in the given DR is calculated as:

$$
p_{i}=\int_{d r}^{d r^{u}} p_{s}\left(\mathrm{FR}_{i}\right) d \mathrm{FR}_{i}
$$

where $p_{s}\left(F R_{i}\right)$ is the system pdf of $F R_{i} \cdot d r^{l}$ and $d r^{u}$ are the lower and upper bounds of DR. In other words, the probability of success $p_{i}$ is calculated by integrating the system pdf over the complete DR and it is nothing but the area of system pdf over the common range $\left(A_{c r}\right)$, as shown in Figure 3 (Suh 1990). Therefore, $I C_{i}$ can be now expressed as follows:

$$
\mathrm{IC}_{i}=\log _{2}\left(\frac{1}{\mathrm{~A}_{\mathrm{cr}}}\right) .
$$

\section{FAD-based approach for personnel selection}

For solving the personnel selection problem, the methodology based on FAD principles is outlined in the framework as shown in Figure 4.

Various procedural steps of the adopted methodology are briefly explained as below:

Step 1: First of all, a selection committee consisting of some experts is required to be constituted taking into consideration 
the job profile of the personnel to be recruited. In this paper, a post of Deputy Manager of a purchase department needs to be filled up. This post belongs to the middle management strata of the organization, and the concerned job profile has many critical and strategic functions, requiring technical knowledge, analytical ability, interpersonal skills and managerial skills. In order to assess these skill sets, a selection committee comprising of one expert each from purchase department, human resources department, technical education field and human psychology field is thus formed.

Step 2: A set of major criteria which are necessary for identifying the requirements of the job, is defined by the expert's committee. In order to have the clarity and precision about the personality traits to be evaluated, the major criteria are then sub-divided further as necessary.

Step 3: In order to have a critical and distinguishing evaluation of the personnel alternatives, an 11-point fuzzy scale is devised for the subsequent rating purpose. For defining the DR values of the major criteria, a five point fuzzy scale is also considered.

Step 4: Each prospective candidate is then examined by all the members of the constituted selection committee. Based on the field of expertise of the selection committee members, the corresponding criteria are evaluated against the fuzzy scale ratings. Considering the relative importance of the major criteria, the selection committee members set the DR values of those criteria.

Step 5: Assessments of the sub-criteria are aggregated (Kannan et al. 2015) using Eq. (7). Let $C_{i}\left(a_{i}, b_{i}, c_{i}\right)$ be the major criterion to be aggregated having $C_{i 1}, C_{i 2}, C_{i 3}, \ldots, C_{i k}$ as

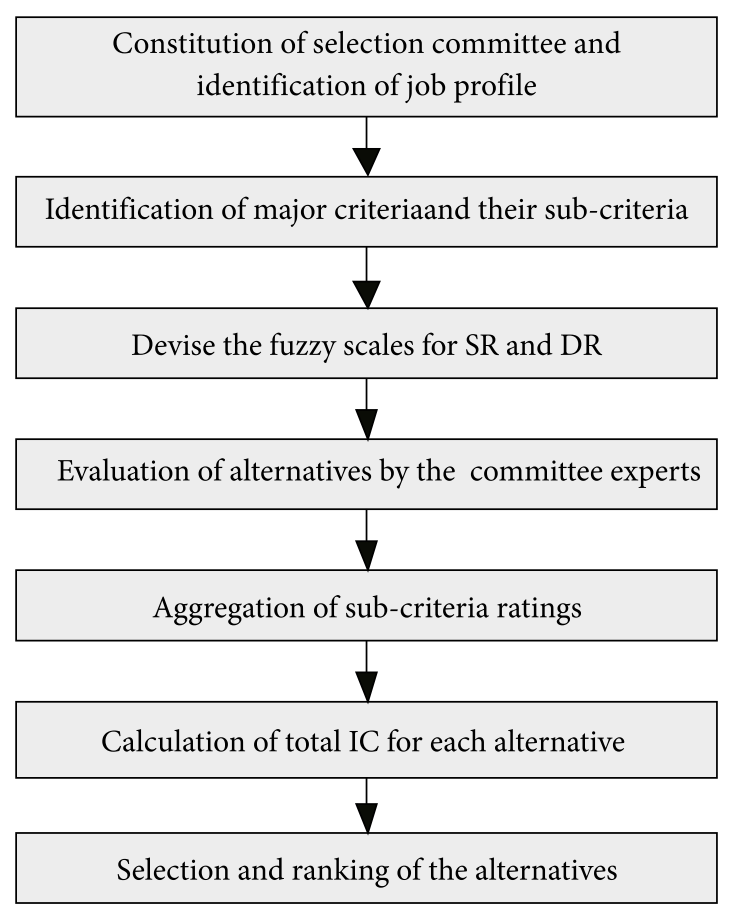

Fig. 4. Framework of FAD-based methodology its sub-criteria. Therefore, the aggregated value is obtained as follows:

$$
\begin{aligned}
& \mathrm{C}_{i}=\frac{\left(\mathrm{C}_{i 1}+\mathrm{C}_{i 2}+\mathrm{C}_{i 3}+. . .+C_{i k}\right)}{k}=\left(a_{i}, b_{i} c_{i}\right), \text { where } \\
& a_{i}=\frac{\left(a_{i 1}+a_{i 2}+a_{i 3}+. .+a_{i k}\right)}{k} ; \\
& b_{i}=\frac{\left(b_{i 1}+b_{i 2}+b_{i 3}+. .+b_{i k}\right)}{k} ; \\
& c_{i}=\frac{\left(c_{i 1}+c_{i 2}+c_{i 3}+. .+c_{i k}\right)}{k},
\end{aligned}
$$

and $k$ is the number of sub-criteria.

Step 6: Individual IC values for all the major criteria are then calculated applying Eq. (4) and are added up to derive the total $I C$ value for each alternative.

Step 7: The total IC values of all the personnel alternatives are arranged in ascending order for subsequent ranking.

\section{Illustrative problem}

A post of Deputy Manager of a purchase department in a large scale manufacturing organization is considered here to be filled up. The set of selection criteria for this post consists of seven major groups which are further divided into some sub-criteria, as given in Table 2.

Since the concerned post belongs to middle management strata, a preliminary screening is performed to shortlist five candidates for the final review. These five candidates are denoted as $\mathrm{P}_{1}, \mathrm{P}_{2}, \mathrm{P}_{3}, \mathrm{P}_{4}$ and $\mathrm{P}_{5}$ to be evaluated by a selection committee consisting of experts from the related fields of human resource, purchase department, top management and technical education. An 11-point scale, expressed in TFNs in Table 3, is employed for assessing the worthiness of candidates with respect to all the criteria.

The evaluation results of the five personnel alternatives as derived by the selection committee experts are depicted in a consolidated form in Table 4. Now, the sub-criteria under each criterion are aggregated while applying Eqn. (7) and the resultant personnel evaluation data in terms of TFNs is presented in Table 5. According to FAD methodology, it is the SR data of the alternatives. The design goals, i.e. DR for the seven criteria are decided while using a five point linguistic scale set as least poor (LP), least fair (LF), least good (LG), least very good (LVG) and least excellent (LE) with their corresponding TFNs as $(0,10,10),(2,10,10)$, $(4,10,10),(6,10,10)$ and $(8,10,10)$ respectively (Maldonado et al. 2013). The selection committee has unanimously decided on the DRs of the seven criteria of strategic skills $\left(C_{1}\right)$, process management skills $\left(C_{2}\right)$, team skills $\left(C_{3}\right)$, decisionmaking skills $\left(\mathrm{C}_{4}\right)$, behavioural skills $\left(\mathrm{C}_{5}\right)$, negotiation skills $\left(\mathrm{C}_{6}\right)$ and quantitative skills $\left(\mathrm{C}_{7}\right)$ as $\mathrm{LE}, \mathrm{LE}, \mathrm{LG}, \mathrm{LE}, \mathrm{LG}, \mathrm{LVG}$ and LVG respectively. The next step of this methodology involves in determination of $I C$ value for an alternative with respect to each criterion. Let us find out the $I C$ value of the 
Table 2. Skills required for a world-class purchaser (Giunipero, Pearcy 2000)

\begin{tabular}{|c|c|c|}
\hline $\begin{array}{l}\text { Strategic skills }\left(\mathrm{C}_{1}\right) \\
\text { - Structuring of suppliers }\left(\mathrm{C}_{11}\right) \\
\text { - Technology planning }\left(\mathrm{C}_{12}\right) \\
\text { - Cost targeting }\left(\mathrm{C}_{13}\right)\end{array}$ & $\begin{array}{l}\text { Management skills }\left(\mathrm{C}_{2}\right) \\
\text { - Time management }\left(\mathrm{C}_{21}\right) \\
\text { - Written communication }\left(\mathrm{C}_{22}\right) \\
\text { - Conflict resolution }\left(\mathrm{C}_{23}\right)\end{array}$ & $\begin{array}{l}\text { Team skills }\left(\mathrm{C}_{3}\right) \\
\text { - Leadership }\left(\mathrm{C}_{31}\right) \\
\text { - Customer focus }\left(\mathrm{C}_{32}\right) \\
\text { - Salesmanship }\left(\mathrm{C}_{33}\right)\end{array}$ \\
\hline \multirow[t]{2}{*}{ Decision-making skills $\left(\mathrm{C}_{4}\right)$} & $\begin{array}{l}\text { Behavioral skills }\left(\mathrm{C}_{5}\right) \\
\text { - Verbal communication }\left(\mathrm{C}_{51}\right) \\
\text { - Entrepreneurship }\left(\mathrm{C}_{52}\right) \\
\text { - Creativity }\left(\mathrm{C}_{53}\right)\end{array}$ & $\begin{array}{l}\text { Negotiation skills }\left(\mathrm{C}_{6}\right) \\
\text { - Persuasiveness }\left(\mathrm{C}_{61}\right) \\
\text { - Understanding the business }\left(\mathrm{C}_{62}\right)\end{array}$ \\
\hline & $\begin{array}{l}\text { Quantitative skills }\left(\mathrm{C}_{7}\right) \\
\text { - Purchasing experience }\left(\mathrm{C}_{71}\right) \\
\text { - Technical proficiency }\left(\mathrm{C}_{72}\right) \\
\text { - Computer literacy }\left(\mathrm{C}_{73}\right)\end{array}$ & \\
\hline
\end{tabular}

personnel alternative $\mathrm{P}_{5}$ for the first job criterion of strategic skills $\left(\mathrm{C}_{1}\right)$. For this alternative-criterion pair of $\mathrm{P}_{5}-\mathrm{C}_{1}$, the TFNs of SR and DR are $(7,8,8.67)$ and $(8,10,10)$ respectively, as shown in Figure 5. In this figure, these SR and DR values are represented by the triangles $\mathrm{ABC}$ and $\mathrm{PQR}$ respectively. The triangle $\mathrm{PNC}$ represents the common range and its area is calculated as 0.0841 sq. units. The area of triangle $A B C$ equals to 0.835 sq. units and it is the value of SR. Therefore, using Eq. (4), the $I C$ value for $\mathrm{P}_{5}-\mathrm{C}_{1}$ pair is calculated as 3.3122. This procedure is repeated for all the alternativecriterion combinations and the resultant values of $I C_{1}$ (IC for $C_{1}$ ) to $I C_{7}$ are depicted in Table 6.

It is observed that the personnel alternative $\mathrm{P}_{3}$ is not at all satisfying the designed values of first four criteria of strategic skills $\left(\mathrm{C}_{1}\right)$, management skills $\left(\mathrm{C}_{2}\right)$, team skills $\left(\mathrm{C}_{3}\right)$ and decision-making skills $\left(\mathrm{C}_{4}\right)$ as laid down by the expert committee members. In other words, the corresponding values of $I C$ are "INFINITE" and the personnel alternative
Table 3. Fuzzy scale for rating the candidate alternatives (Kelemenis et al. 2011)

\begin{tabular}{|l|c|}
\hline \multicolumn{1}{|c|}{ Linguistic value } & TFN \\
\hline Definitely poor (DP) & $(0,0,1)$ \\
\hline Extremely poor (EP) & $(0,1,2)$ \\
\hline Very poor (VP) & $(1,2,3)$ \\
\hline Poor (P) & $(2,3,4)$ \\
\hline Medium poor (MP) & $(3,4,5)$ \\
\hline Fair (F) & $(4,5,6)$ \\
\hline Medium good (MG) & $(5,6,7)$ \\
\hline Good (G) & $(6,7,8)$ \\
\hline Very good (VG) & $(7,8,9)$ \\
\hline Extremely good (EG) & $(8,9,10)$ \\
\hline Definitely good (DG) & $(9,10,10)$ \\
\hline
\end{tabular}

Table 4. Assessment by the committee experts

\begin{tabular}{|c|c|c|c|c|c|c|c|c|c|c|c|c|c|c|c|c|c|c|}
\hline \multirow{2}{*}{$\begin{array}{l}\text { Alter- } \\
\text { native }\end{array}$} & \multicolumn{3}{|c|}{$\mathrm{C}_{1}$} & \multicolumn{3}{|c|}{$\mathrm{C}_{2}$} & \multicolumn{3}{|c|}{$\mathrm{C}_{3}$} & $\mathrm{C}_{4}$ & \multicolumn{3}{|c|}{$\mathrm{C}_{5}$} & \multicolumn{2}{|c|}{$\mathrm{C}_{6}$} & \multicolumn{3}{|c|}{$\mathrm{C}_{7}$} \\
\hline & $\mathrm{C}_{11}$ & $\mathrm{C}_{12}$ & $\mathrm{C}_{13}$ & $\mathrm{C}_{21}$ & $\mathrm{C}_{22}$ & $\mathrm{C}_{23}$ & $\mathrm{C}_{31}$ & $\mathrm{C}_{32}$ & $\mathrm{C}_{33}$ & $\mathrm{C}_{4}$ & $\mathrm{C}_{51}$ & $\mathrm{C}_{52}$ & $\mathrm{C}_{53}$ & $\mathrm{C}_{61}$ & $\mathrm{C}_{62}$ & $\mathrm{C}_{71}$ & $\mathrm{C}_{72}$ & $\mathrm{C}_{73}$ \\
\hline $\mathrm{P}_{1}$ & G & VG & VG & EG & EG & $\mathrm{MG}$ & $\mathrm{G}$ & $\mathrm{P}$ & $\mathrm{F}$ & VG & MP & $\mathrm{G}$ & VP & $\mathrm{P}$ & VG & VG & $\mathrm{F}$ & MG \\
\hline $\mathrm{P}_{2}$ & EG & VG & G & EG & DG & G & MG & $\mathrm{F}$ & VG & VG & EG & $\mathrm{P}$ & MG & G & EG & $\mathrm{MG}$ & G & G \\
\hline $\mathrm{P}_{3}$ & $\mathrm{~F}$ & EG & G & DG & MG & $\mathrm{P}$ & EP & $\mathrm{F}$ & $\mathrm{DP}$ & MG & $\mathrm{F}$ & $\mathrm{G}$ & VG & $\mathrm{VP}$ & EG & $\mathrm{G}$ & EG & VG \\
\hline $\mathrm{P}_{4}$ & EG & MG & VG & MG & EG & VG & VG & $\mathrm{G}$ & EG & EG & VG & EG & VG & G & MG & VG & $\mathrm{F}$ & MG \\
\hline $\mathrm{P}_{5}$ & VG & MG & DG & VG & DG & DG & EG & VG & DG & EG & VG & DG & VG & EG & EG & EG & MG & VG \\
\hline
\end{tabular}

Table 5. SR data of the alternatives

\begin{tabular}{|c|c|c|c|c|c|c|c|}
\hline $\begin{array}{c}\text { Alter- } \\
\text { native }\end{array}$ & $\mathrm{C}_{1}$ & $\mathrm{C}_{2}$ & $\mathrm{C}_{3}$ & $\mathrm{C}_{4}$ & $\mathrm{C}_{5}$ & $\mathrm{C}_{6}$ & $\mathrm{C}_{7}$ \\
\hline $\mathrm{P}_{1}$ & $(6.67,7.67,8.67)$ & $(7,8,9)$ & $(4,5,6)$ & $(7,8,9)$ & $(3.33,4.33,5.33)$ & $(4.5,5.5,6.5)$ & $(5.33,6.33,7.33)$ \\
\hline $\mathrm{P}_{2}$ & $(7,8,9)$ & $(7.67,8.67,9.33)$ & $(5.33,6.33,7.33)$ & $(7,8,9)$ & $(5,6,7)$ & $(7,8,9)$ & $(5.67,6.67,7.67)$ \\
\hline $\mathrm{P}_{3}$ & $(6,7,8)$ & $(5.33,6.33,7.0)$ & $(1.33,2,3)$ & $(5,6,7)$ & $(5.67,6.67,7.67)$ & $(4.5,5.5,6.5)$ & $(7,8,9)$ \\
\hline $\mathrm{P}_{4}$ & $(6.67,7.67,8.67)$ & $(6.67,7.67,8.67)$ & $(7,8,9)$ & $(8,9,10)$ & $(7.33,8.33,9.33)$ & $(5.5,6.5,7.5)$ & $(5.33,6.33,7.33)$ \\
\hline $\mathrm{P}_{5}$ & $(7,8,8.67)$ & $(8.33,9.33,9.67)$ & $(8,9,9.67)$ & $(8,9,10)$ & $(7.67,8.67,9.33)$ & $(8,9,10)$ & \\
\hline
\end{tabular}


Table 6. Ranking of the personnel alternatives

\begin{tabular}{|c|c|c|c|c|c|c|c|c|c|}
\hline \multirow{2}{*}{ Alternative } & \multicolumn{7}{|c|}{ Information content } & \multirow{2}{*}{$\mathrm{IC}_{\mathrm{TOTAL}}$} & \multirow{2}{*}{ Rank } \\
\hline & $\mathrm{IC}_{1}$ & $\mathrm{IC}_{2}$ & $\mathrm{IC}_{3}$ & $\mathrm{IC}_{4}$ & $\mathrm{IC}_{5}$ & $\mathrm{IC}_{6}$ & $\mathrm{IC}_{7}$ & & \\
\hline $\mathrm{P}_{1}$ & 3.7405 & 2.585 & 1.8074 & 2.585 & 2.9845 & 5.3219 & 2.4991 & 21.5234 & 4 \\
\hline $\mathrm{P}_{2}$ & 2.585 & 1.3198 & 0.7009 & 2.585 & 0.8814 & 0.4475 & 1.8422 & 10.3618 & 2 \\
\hline $\mathrm{P}_{3}$ & INFINITE & INFINITE & INFINITE & INFINITE & 0.5497 & 5.3219 & 0.4475 & INFINITE & 5 \\
\hline $\mathrm{P}_{4}$ & 3.7405 & 3.7405 & 0.1751 & 0.585 & 0.1198 & 2.152 & 2.4991 & 13.012 & 3 \\
\hline $\mathrm{P}_{5}$ & 3.3122 & 0.169 & 0.0439 & 0.585 & 0.0787 & 0.0995 & 0.6482 & 4.9365 & 1 \\
\hline
\end{tabular}

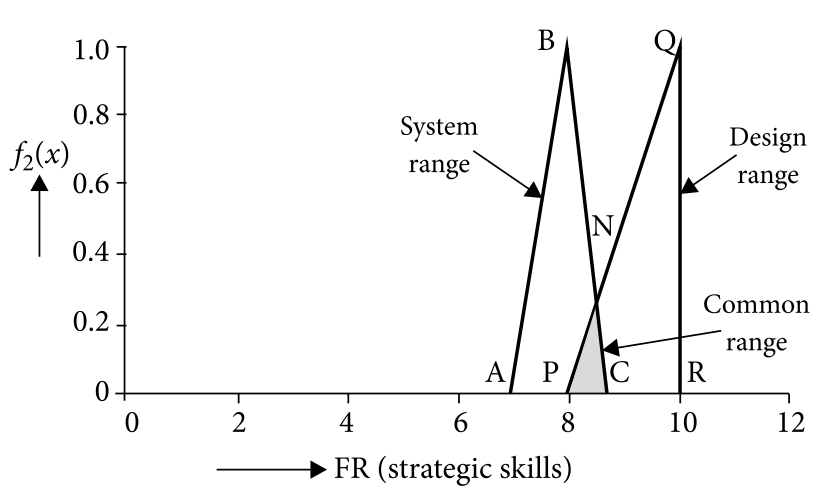

Fig. 5. System range, design range and common range for $\mathrm{P}_{5}-\mathrm{C}_{1}$ pair

$\mathrm{P}_{3}$ becomes totally unsuitable for the desired post. From Table 6 , it can be observed that personnel alternative $\mathrm{P}_{5}$ has the least value of $\mathrm{IC}_{\mathrm{TOTAL}}$ amongst the remaining four alternatives and hence, according to the adopted AD methodology, it is judged to be the most favourable choice of the selectors. On the contrary, $\mathrm{IC}_{\mathrm{TOTAL}}$ value of personnel alternative $\mathrm{P}_{1}$ is the highest and hence, it is the last choice for the proposed post. With alternative $\mathrm{P}_{3}$ as rejected one, the remaining personnel alternatives are arranged in increasing order of their $\mathrm{IC}_{\text {TOTAL }}$ values as $\mathrm{P}_{5}-\mathrm{P}_{2}-\mathrm{P}_{4}-\mathrm{P}_{1}$.

\section{Conclusions}

In today's highly competitive manufacturing organizations, it is utmost necessary to have the right and appropriate person at every job position. The middle management level position of a Deputy Manager of a purchase department, as considered for selection in this paper, is far more critical and the incumbent is solely responsible for efficient functioning of the department. Therefore, it is necessary that the selection procedure for the said post is carried out by some competent authority while adopting a scientific and systematic procedure. The job nature of this post demands for techno-commercial and managerial competencies in the prospective candidate. Concomitantly, a committee of experts from the related fields is constituted for that purpose. The personnel alternatives are evaluated with respect to a set of 18 different skills and attitudes by the selection committee.
The adopted AD methodology is based on two axioms, out of which information axiom is employed here for the decision-making purpose. Information axiom works on the principle of comparing the given criterion value with its desired value and provides $I C$ value as the deciding factor. Therefore, the outcomes of this method are quite logical. All the evaluation data of this present decision-making problem is expressed qualitatively, and hence, TFNs are employed for tapping the imprecision involved and for further processing. The least total $I C$ value of the personnel alternative $\mathrm{P}_{5}$ identifies the said candidate to be the most appropriate for the job position.

The practical value of this paper becomes more evident in the context of today's personnel selection in technological world. As against the pre-industrial revolution, various job positions have become very specific in terms of functions and responsibilities to be carried out by the incumbents concerned. Hence, responsibility of the recruiters is also increased many folds in selecting the appropriate personnel as compared to their previous counterparts. In other words, it has become quite urgent and necessary to have the congruence between the job functionalities and the corresponding skills set of the prospective candidates. This activity of personnel selection is also an ongoing process at all the hierarchical levels of the organizations, irrespective of their nature of work. Therefore, the methodology adopted in this paper for personnel selection is the most appropriate tool as it works exactly with the underlying principle of matching the functionality expectations in terms of DR with the qualification traits of the personnel, expressed both subjectively and objectively, in terms of SR. As a result, the probability of recruiting the most befitting personnel for the concerned job positions gets enhanced. This process of selecting the right type of personnel gets reflected in the long term benefits of the organization as continued and meaningful employment of the personnel resulting into productivity improvement. It also results in more job satisfaction, less amount of job hopping, professional progress and stability of the employees.

By using this methodology, it is also possible to judge the relative performance or suitability of the personnel alternatives with respect to the chosen criterion. Hence, it can 
be applied for self performance appraisal. As a result, one can identify the weaker aspects and take necessary actions for further improvement.

There are many critical decision-making areas in manufacturing organizations, such as process selection, plant location selection, supplier selection, layout selection etc. involving ambiguous scenario. So, the present methodology can be of great help in all these decision-making problems due to its scientific and logical background. There is no restriction on the number of alternatives and criteria while applying this methodology. It can also simultaneously handle a mix of qualitative and quantitative data with less number of simple calculation steps for arriving at the most decisive course of action.

\section{References}

Afshari, A.; Mojahed, M.; Yusuff, R. M. 2010. Simple additive weighting approach to personnel selection problem, International Journal of Innovation, Management and Technology 1(5): 511-515.

Afshari, A. R.; Yusuff, R. M.; Derayatifar, A. R. 2013. Linguistic extension of fuzzy integral for group personnel selection problem, Arabian Journal for Science and Engineering 38(10): 2901-2910. http://dx.doi.org/10.1007/s13369-012-0491-z

Aggarwal, R. 2013. Selection of IT personnel through hybrid multi-attribute AHP-FLP approach, International Journal of Soft Computing and Engineering 2(6): 11-17.

Akhlaghi, E. 2011. A rough-set based approach to design an expert system for personnel selection, World Academy of Science, Engineering and Technology 5(6): 202-205.

Baležentis, A.; Baležentis, T.; Brauers, W. K. M. 2012. Personnel selection based on computing with words and fuzzy MULTIMOORA, Expert Systems with Applications 39(9): 7961-7967. http://dx.doi.org/10.1016/j.eswa.2012.01.100

Baležentis, T.; Zeng, S. 2013. Group multi-criteria decision making based upon interval-valued fuzzy numbers: an extension of the MULTIMOORA method, Expert Systems with Applications 40(2): 543-550.

http://dx.doi.org/10.1016/j.eswa.2012.07.066

Bali, Ö.; Gümüş, S.; Dağdeviren, M. 2013. A group MADM method for personnel selection problem using Delphi technique based on intuitionistic fuzzy sets, Journal of Military and Information Science 1(1): 1-13.

Beng, L. G.; Omar, B. 2014. Integrating axiomatic design principles into sustainable product development, International Journal of Precision Engineering and Manufacturing-Green Technology 1(2): 107-117.

http://dx.doi.org/10.1007/s40684-014-0015-2

Boran, F. E.; Genç, S.; Akay, D. 2011. Personnel selection based on intuitionistic fuzzy sets, Human Factors and Ergonomics in Manufacturing \& Service Industries 21(5): 493-503. http://dx.doi.org/10.1002/hfm.20252

Boran, F. E.; Boran, K.; Dizdar, E. 2012. A fuzzy multi criteria decision making to evaluate energy policy based on an information axiom: a case study in Turkey, Energy Sources, Part B: Economics, Planning, and Policy 7(3): 230-240. http://dx.doi.org/10.1080/15567240902839294
Büyüközkan, G. 2012. An integrated fuzzy multi-criteria group decision-making approach for green supplier evaluation, International Journal of Production Research 50(11): 28922909. http://dx.doi.org/10.1080/00207543.2011.564668

Celik, M.; Kandakoglu, A.; Er, I. D. 2009. Structuring fuzzy integrated multi-stages evaluation model on academic personnel recruitment in MET institutions, Expert Systems with Applications 36(3/2): 6918-6927.

Chaghooshi, A. J.; Janatifar, H.; Dehghan, M. 2014. An application of AHP and similarity-based approach to personnel selection, International Journal of Business Management and Economics 1(1): 24-32.

Chen, C.-T.; Pai, P.-F.; Hung, W.-Z. 2011. Applying linguistic VIKOR and knowledge map in personnel selection, Asia Pacific Management Review 16(4): 491-502.

Cicek, K.; Celik, M. 2010. Multiple attribute decision-making solution to material selection problem based on modified fuzzy axiomatic design-model selection interface algorithm, Materials and Design 31(4): 2129-2133. http://dx.doi.org/10.1016/j.matdes.2009.11.016

Dağdeviren, M. 2010. A hybrid multi-criteria decision-making model for personnel selection in manufacturing systems, Journal of Intelligent Manufacturing 21(4): 451-460. http://dx.doi.org/10.1007/s10845-008-0200-7

Dereli, T.; Durmuşoğlu, A.; Seçkiner, S. U.; Avlanmaz, N. 2010. A fuzzy approach for personnel selection process, Turkish Journal of Fuzzy Systems 1(2): 126-140.

Dodangeh, J.; Sorooshian, S.; Afshari, A. R. 2014. Linguistic extension for group multicriteria project manager selection, Journal of Applied Mathematics, Article ID 570398. http://dx.doi.org/10.1155/2014/570398

Dursun, M.; Karsak, E. E. 2010. A fuzzy MCDM approach for personnel selection, Expert Systems with Applications 37(6): 4324-4330. http://dx.doi.org/10.1016/j.eswa.2009.11.067

Gilan, S. S.; Sebt, M. H.; Shahhosseini, V. 2012. Computing with words for hierarchical competency based selection of personnel in construction companies, Applied Soft Computing 12(2): 860-871. http://dx.doi.org/10.1016/j.asoc.2011.10.004

Giunipero, L. C.; Pearcy, D. H. 2000. World-class purchasing skills: an empirical investigation, The Journal of Supply Chain Management 36(3): 4-13. http://dx.doi.org/10.1111/j.1745-493X.2000.tb00081.x

Güngör, Z.; Serhadlığlu, G.; Kesen, S. E. 2009. A fuzzy AHP approach to personnel selection problem, Applied Soft Computing 9(2): 641-646. http://dx.doi.org/10.1016/j.asoc.2008.09.003

Javadein, S. R. S.; Fathi, M. R.; Behrooz, A.; Sadeghi, M. R. 2013. Human resource manager selection based on logarithmic fuzzy preference programming and TOPSIS methods, International Journal of Human Resource Studies 3(2): 14-27.

Kannan, D.; Govindan, K.; Rajendran, S. 2015. Fuzzy axiomatic design approach based green supplier selection: a case study from Singapore, Journal of Cleaner Production 96: 194-208. http://dx.doi.org/10.1016/j.jclepro.2013.12.076

Kelemenis, A.; Askounis, D. 2010. A new TOPSIS-based multicriteria approach to personnel selection, Expert Systems with Applications 37(7): 4999-5008. http://dx.doi.org/10.1016/j.eswa.2009.12.013

Kelemenis, A.; Ergazakis, K.; Askounis, D. 2011. Support managers' selection using an extension of fuzzy TOPSIS, Expert Systems with Applications 38(3): 2774-2782. http://dx.doi.org/10.1016/j.eswa.2010.08.068 
Keršulienė, V.; Turskis, Z. 2011. Integrated fuzzy multiple criteria decision making model for architect selection, Technological and Economic Development of Economy 17(4): 645-666. http://dx.doi.org/10.3846/20294913.2011.635718

Kumaran, V. S.; Sankar, A. 2013. Towards an automated system for intelligent screening of candidates for recruitment using ontology mapping (EXPERT), International Journal of Metadata, Semantics and Ontologies 8(1): 56-64.

http://dx.doi.org/10.1504/IJMSO.2013.054184

Lin, H.-T. 2010. Personnel selection using analytic network process and fuzzy data envelopment analysis approaches, Computers \& Industrial Engineering 59(4): 937-944. http://dx.doi.org/10.1016/j.cie.2010.09.004

Li, M. 2013. Extension of axiomatic design principles for multicriteria decision making problems in intuitionistic fuzzy environment, Mathematical Problems in Engineering, Article ID 813471. http://dx.doi.org/10.1155/2013/813471

Matin, H. Z.; Fathi, M. R.; Zarchi, M. K.; Azizollahi, S. 2011. The application of fuzzy TOPSIS approach to personnel selection for Padir Company, Iran, Journal of Management Research 3(2): 1-14.

Maldonado, A.; García, J. L.; Alvarado, A.; Balderrama, C. O. 2013. A hierarchical fuzzy axiomatic design methodology for ergonomic compatibility evaluation of advanced manufacturing technology, International Journal of Advanced Manufacturing Technology 66(1-4): 171-186. http://dx.doi.org/10.1007/s00170-012-4316-8

Monczka, R. M.; Handfield, R. B.; Giunipero, L. C.; Patterson, J. L. 2009. Purchasing and supply chain management. South-Western Cengage Learning, USA.

Nobari, S. M.; Zadeh, D. H. 2013. Designing a fuzzy model for decision support systems in the selection and recruitment process, African Journal of Business Management 7(16): 1486-1491.

Özdemir, A. 2013. A two-phase multi criteria dynamic programing approach for personnel selection process, Problems and Perspectives in Management 11(2): 98-108.

Rashidi, A.; Jazebi, F.; Brilakis, I. 2011. Neurofuzzy genetic system for selection of construction project managers, Journal of Construction Engineering and Management 137(1): 17-29. http://dx.doi.org/10.1061/(ASCE)CO.1943-7862.0000200
Rouyendegh, B. D.; Erkan, T. E. 2013. An application of the fuzzy ELECTRE method for academic staff selection, Human Factors and Ergonomics in Manufacturing \& Service Industries 23(2): 107-115. http://dx.doi.org/10.1002/hfm.20301

Saad, R. M.; Ahmad, M. Z.; Abu, M. S.; Jusoh, M. S. 2014. Hamming distance method with subjective and objective weights for personnel selection, Scientific World Journal, Article ID 865495. http://dx.doi.org/10.1155/2014/865495

Safari, H.; Virgilio, C.-M.; Sarraf, A. Z.; Maleki, M. 2014. Multidimensional personnel selection through combination of TOPSIS and Hungary assignment algorithm, Management and Production Engineering Review 5(1): 42-50. http://dx.doi.org/10.2478/mper-2014-0006

Shahhosseini, V.; Sebt, M. H. 2011. Competency-based selection and assignment of human resources to construction projects, Scientia Iranica 18(2): 163-180. http://dx.doi.org/10.1016/j.scient.2011.03.026

Sîrb, L.; Dragolea, L. 2013. A qualitative approach in terms of fuzzy logic related to the excellence achieving within managerial process of personnel selection, Polish Journal of Management Studies 7(1): 48-57.

Straub, A.; Mossel, H.-J. 2007. Contractor selection for performance-based maintenance partnerships, International Journal of Strategic Property Management 11(2): 65-76.

Suh, N. P. 1990. The principles of design. New York: Oxford University Press.

Suh, N. P. 2001. Axiomatic design: advances and applications. New York: Oxford University Press.

Wan, S.-P.; Wang, Q.-Y.; Dong, J.-Y. 2013. The extended VIKOR method for multi-attribute group decision making with triangular intuitionistic fuzzy numbers, Knowledge-Based Systems 52: 65-77. http://dx.doi.org/10.1016/j.knosys.2013.06.019

Zadeh, L. A. 1996. Fuzzy logic = computing with words, IEEE Transactions on Fuzzy Systems 4(2): 103-111. http://dx.doi.org/10.1109/91.493904

Zhang, S.-F.; Liu, S.-Y. 2011. A GRA-based intuitionistic fuzzy multi-criteria group decision making method for personnel selection, Expert Systems with Applications 38(9): 1140111405. http://dx.doi.org/10.1016/j.eswa.2011.03.012

Anant V. KHANDEKAR is working as a Senior lecturer at Government Polytechnic, Mumbai (India). He graduated in Mechanical Engineering from Government College of Engineering, Amravati, Maharashtra (India) in 1989. He obtained his Masters in Manufacturing Technology from Thapar Institute of Engineering and Technology, Patiala (India) in 2002. He has published a few papers in journals of international repute as well as presented his work in some conferences. At present, he is pursuing his PhD (Engg) research work at Jadavpur University, Kolkata (India) and his research interests include the applications of fuzzy multicriteria decision-making techniques in manufacturing environment.

Shankar CHAKRABORTY is a Professor in Production Engineering Department of Jadavpur University. He graduated in 1986 from University of Calcutta and obtained his post-graduate degree from Jadavpur University in 1989. He had been awarded with $\mathrm{PhD}$ (Engg.) from Jadavpur University in 1994. His research interests are in the areas of applications of different multi-criteria decision-making methods in manufacturing environment, control chart pattern recognition, and development of MIS and ERP systems for engineering applications. He has guided several $\mathrm{ME}$ and $\mathrm{PhD}$ (Engg.) theses, and published numerous papers in international journals. He is a regular reviewer of several international journals. 